\title{
Supporting Issues
}

The following peripheral issues help to deepen the understanding of the limited role that due process has played in EU competition law: (1) The growing importance of system thinking in social sciences; (2) The New Public Management movement; (3) The distinction between people, consumers and citizens; (4) The accession of the European Union to the ECHR and (5) The EU Charter of Fundamental Rights.

There are two main frameworks to analyse the world or any subject: topical, focused on one part only, or holistic, focusing on the whole that is formed by interacting parts. The second approach can be dated back to Aristotle's claim that knowledge can only be derived from the understanding of the whole rather than its parts. It was, however, only in the 2oth century that this adage broke free from the constraints of popular wisdom when systems theory began to be legitimized as an interdisciplinary tool for analysis. Although systems theory had been initially and predominantly used in cybernetics, chemistry and biology, it quickly rose to prominence within the analytical ranks of social scientists as well. Currently, systems theory provides one of the most potent tools for analysis in any field of study.

Systems theory produces interesting findings when unmoored from its initial, classical science background. Katz and Kahn, for example, have successfully applied systems thinking to organizations, defined by them as open systems constantly re-defined by their interactions with the environment. ${ }^{1}$ This has resulted in management gurus and practitioners fully embracing systems theory. Luhmann brought the systems theory matrix of analysis to sociology, politics and law, providing one of the most extensive, complex and compelling theories of society. ${ }^{2}$

A system is defined as "a set of things - people, cells, molecules, whatever interconnected in such a way that they produce their own pattern of behaviour

1 Katz, Daniel, and Robert L. Kahn. The Social Psychology of Organization. New York:Wiley, 1966.

2 Luhmann, Niklas. Social Systems. Stanford: Stanford University Press, 1995. 
over time". ${ }^{3}$ Von Bertalanffy places interaction between parts or between the parts and their environment at the core of every existing system. ${ }^{4}$ Tien and Berg go along the same lines when they define the types of systems and their components:

A system can be natural (e.g., lake) or built (e.g., government), physical (e.g., space shuttle) or conceptual (e.g., plan), closed (e.g., chemicals in a stationary, closed bottle) or open (e.g., tree), static (e.g., bridge) or dynamic (e.g., human). In regard to its elements, a system can be detailed in terms of its components, composed of people, processes and products; its attributes, composed of the input, process and output characteristics of each component; and its relationships, composed of interactions between components and characteristics. ${ }^{5}$

Meadows highlights the relationship between the structure of the system and the behaviours exhibited by its elements and adds that "the least obvious part of the system, its function or purpose, is often the most crucial determinant of the system's behaviour". ${ }^{6}$

The current work attempts to apply the basic elements of systems theory to the field of fundamental rights protection in Europe. The use of systems theory can support attempts to explain why EU competition law has remained resistant to the developments in the field of fundamental rights in the EU. Systems theory also provides a clarification of the deferential judicial review performed and preferred by the EU courts. Lastly, and probably most importantly, the exercise of applying systems theory to the ECtHR results in arguing that the latter is a self-regulating tribunal.

\section{2}

\section{The New Public Management Movement}

Neither the Commission, in all its roles, nor the ECtHR have escaped the influence of the most important movement in administrative theory from the second half of the 2oth century - the New Public Management. This

3 Meadows, Donella H. Thinking in Systems: A Primer. London: Earthscan, 20og. Page 2.

4 Von Bertalanffy, Ludwig. "General Systems Theory." General Systems, Yearbook of Society for General Systems Research 1 (1956): pp. 1-10.

5 Tien, James M., and Daniel Berg. "A Case for Service Systems Engineering." Journal of Systems Science and Systems Engineering 12.1 (2003): pp. 23-24.

6 Meadows, Donella H. Thinking in Systems: A Primer. London: Earthscan, 20o9, p. 16. 
section provides a description of the NPM movement and its influence on the Commission and the ECtHR.

The National Partnership for Reinventing Government and the National Performance Review were launched by US President Bill Clinton in March 1993. The goal of the endeavour has been to "make the entire federal government both less expensive and more efficient, and to change the culture of our national bureaucracy away from complacency and entitlement toward initiative and empowerment". ${ }^{7}$ Based on this goal, the Phase I report, Creating a Government That Works Better and Costs Less, made 384 recommendations. It was supported by 38 "accompanying" reports which detailed 1,250 specific actions intended to save $\$ 108$ billion in total, reduce the number of "overhead" positions, and improve government operations. ${ }^{8}$

What started as an American phenomenon quickly spread and gained momentum in the rest of the world as well. The importance of the American origin of this theory and phenomenon should not be overlooked. Caiden wrote that "most of the theories employed have originated in the United States. Most of the substantive measures advocated are drawn from American texts. Many of the experts employed by international bodies to expound the platform are Americans. Most models and sample laws are based on American sources". 9

In his seminal work Dismantling Democratic States, Suleiman points out that all US Presidents have launched programs for government reorganization and for the elimination of waste. The proposal put forward by the ClintonGore administration differed from all the previous programs in two ways. First, the scope of proposed changes had not been previously matched. Second, and more importantly, this proposal suggested the

embrace of norms that had hitherto been considered appropriate only for the private sector - customer orientation, entrepreneurism, competition among government agencies - and the implicit alliance that has

7 Remarks by President Clinton Announcing the Initiative to Streamline Government, 3 March 1993. Available at https://govinfo.library.unt.edu/npr/library/speeches/o3o393.html accessed on 23 February 2021.

8 National Partnership for Reinventing Government/John Kamensky. "A Brief History." January 1999. Available at https://govinfo.library.unt.edu/npr/whoweare/history2.html accessed on 23 February 2021.

9 Caiden, Gerald E. “Administrative Reform - American Style." Public Administration Review 54.2 (1994), p. 124. 
come to be made with social and political forces that seek to curtail the role of government for ideological or class interest. ${ }^{10}$

Suleiman describes four key concepts behind the NPM and how they differ from the previous attempts to reorganize governments: (1) Entrepreneurism; (2) Customer Orientation; (3) Flattening Hierarchies and (4) Alternative Forms of Implementation. Suleiman highlights that "most important in this view is the idea that the dangers of bureaucratic discretion that are said to be concomitant with entrepreneurism are not really dangers at all if bureaucrats are motivated to serve the public interest".11 He notes that some elements of the NPM such as flexibility - defined as "a disdain for red tape coupled with emphasis on getting things done" - and the decreasing attention to formal rules and hierarchies hide a "scepticism about the existence of a public service institution".12 Lastly, Suleiman points that "procedural due process, which is seen as the core legitimating concern that prompts the existence of red tape in the first place, is deemphasized in the literature on government reinvention". (emphasis added $)^{13}$

A few consequences follow from the embrace of the NPM. First, there is a withering of the notion of public interest which, if construed as a flexible notion, justifies a diminished role for public bureaucracy. ${ }^{14}$

Second, in the NPM model, the state becomes a producer of services with citizens as customers. Suleiman notes that "paradoxically, the attempt to promote the consumer and to make him central to the new democracy was an attempt to combat cartels and the plutocrats". ${ }^{15}$ Boorstin's work on consumption communities has argued that "now men were affiliated less by what they believed than by what they consumed". ${ }^{16}$ Suleiman suggests that "the contemporary attempt to see the government as facing a horde of consumers that it needs to satisfy rather than as citizens to whom it has responsibility" is the "antithesis of the kind of citizenship required to sustain a democratic polity".17

\footnotetext{
10 Suleiman, Ezra. Dismantling Democratic States. Princeton: Princeton University Press, 2005, p. 44.

11 Suleiman, op. cit., p. 45-46.

12 Suleiman, op. cit., p 47.

13 Suleiman, op. cit., p 45.

14 Suleiman, op. cit., p. 5 o.

15 Suleiman, op. cit., p. 53.

16 Boorstin, Daniel J. The Americans: The democratic experience. New York: Random House, 1973, p. 147.

17 Suleiman, op. cit., p. 54.
} 
Lastly, Suleiman highlights that the weakening of the idea of collective interest leads to statist minimalism and politics and to the state no longer being able to ensure the impartial arbitration between competing claims. ${ }^{18}$

The NPM model was embraced in the European Union as well. The resignation of the Santer Commission in 1999, following perceived runaway tendencies of the European bureaucracy that culminated with a legitimacy crisis, started a wave of NPM reforms. The Committee of Independent Experts appointed by the EU Parliament in the wake of the crisis found that the EU Commission tolerated fraud and nepotism in breach of the principles of independence, integrity and discretion required from all members of the Commission. ${ }^{19}$ The first report of the experts also found "an admission of a loss of control by the political authorities over the Administration that they supposedly were running". ${ }^{20}$ Ellinas and Suleiman, in their extensive appraisal of the process, suggested that the proposed solution was "to make European officials more responsible through the enhancement of management practices". ${ }^{21}$

The EU Commission's White Paper on Governance of 2001 acknowledged that political leaders throughout Europe were facing a real paradox: "on the one hand, Europeans want them to find solutions to the major problems confronting our societies. On the other hand, people increasingly distrust institutions and politics or are simply not interested in them". ${ }^{22}$ The White Paper on Governance proposed a wide-ranging series of reforms, some of which contain elements of NPM: greater use of policy tools such as regulations, framework directives, guidelines and recommendations, co-regulatory mechanisms and the further creation and development of EU regulatory agencies.

The European Commission under Romano Prodi made administrative reform one of its top priorities. Neil Kinnock was appointed vice president of the Commission and was put in charge of the modernization process of the EU Commission in 2000 .

18 Suleiman, op. cit., pp. 55-59.

19 Committee of Independent Experts. First Report on Allegations Regarding Fraud, Mismanagement and Nepotism in the European Commission.15 Mar 1999. Available at http://www.europarl.europa.eu/experts/pdf/reporten.pdf accessed on 23 February 2021.

20 Committee of Independent Experts, quoted above, p. 137.

21 Ellinas, Antonis A., and Ezra Suleiman. The European Commission and Bureaucratic Autonomy. Cambridge: Cambridge University Press, 2012, p. 99.

22 Commission of the European Communities. European Governance: A White Paper. Brussels: $\operatorname{COM(2001)~} 428$ final. Available at https://ec.europa.eu/europeaid/europeangovernance-white-paper_en accessed on 23 February 2021. 
Ellinas and Suleiman noted that there were four overarching themes of the modernization efforts put forward by the Kinnock Reforms. ${ }^{23}$ The first was a "culture based on service" that led to new standards of behaviour for Commissioners and a Code for Good Administrative Behaviour. ${ }^{24}$ The second theme was efficiency: "echoing NPM-type ideas (...) the overall goal was to encourage the various directorates and departments to focus more on results, rather than procedures". ${ }^{25}$ The third theme of the reform proposal was the improvement of financial management and control, and the improvement of audit procedures. The last theme of the reform initiative was the modernization of human resources policies, and management ability was identified as the most important criterion for appointments. ${ }^{26}$

The reform of the European Commission took place at the same time as the accession of the Eastern countries leaving behind a totalitarian past. Coincidentally, on 1 May 2004, Regulation 1/2003 entered into force and 10 new member states joined the European Union. As will be shown later, Regulation 1/2003 put forward all the NPM elements described above in the enforcement of competition policy in the EU: customer orientation, the flattening of hierarchies, preference for alternative forms of implementation and the disdain for due process that characterizes entrepreneurism-derived flexibility.

The Kinnock reforms have been widely discussed in the academic world. Some observers consider that they have been the most successful attempt at modernizing European bureaucracy. ${ }^{27}$ Other writers have remained sceptical. Ellinas and Suleiman concluded, after extensive interviews with the Commission's officials, that the progress achieved by the Kinnock reforms in modernizing the Commission has come at the expense of increasing its bureaucratization. They highlight that "the Kinnock reforms are probably unique in the universe of NPM-inspired administrative reforms in that they are thought to have reduced efficiency instead of enhancing it". ${ }^{28}$

As to the ECtHR, a recent paper has analysed the impact of NPM reforms put in place since at least 1994 to render the ECtHR more efficient. ${ }^{29}$ Lambert

\footnotetext{
23 Ellinas and Suleiman, op. cit., pp. 101-104.

24 European Commission (2001), quoted above.

25 Ellinas and Suleiman, op. cit., p. 102.

26 Ellinas and Suleiman, op. cit., p. 103.

27 Bauer, Michael. "The Politics of Reforming the European Commission." Management Reforms in International Organizations. Eds. Michael Bauer and Christoph Knill. BadenBaden: Nomos, 2007, p. 52.

28 Ellinas and Suleiman, op. cit., p. 122.

29 Lambert Abdelgawad, Elisabeth. "The Economic Crisis and the Evolution of the System Based on the ECHR: Is There Any Correlation?” European Law Journal 22.1 (2016): pp. 74-91.
} 
Abdelgawad has shown that the efficiency-driven reforms have resulted in a different filtration of applications procedure, in a priority policy and in numerous pilot judgements, allowing the ECtHR to freeze cases until the Member State from which the applications originate solves the matter at the origin of the large number of applications. Efficiency of courts, alongside independence, has become a paramount principle. At the same time, the more worrisome trend has been to equate efficiency with the speed of the judicial decision-making process. Lambert Abdelgawad concluded that "NMP remains dominant if not domineering" and that "efficiency may have resulted in more rulings for each euro, but these savings have come at a very high price, to be paid by individuals whose Convention rights have been breached but who may be prevented from having access to the ECtHR in the very name of maximising the return of financial resources". 30

As it will be shown in Part 3, the NPM movement and the Kinnock reforms have resulted in the adoption of measures strengthening the independence of the Commissioners, but also of the civil service of the EU Commission. At the same time, the impact of the Kinnock reforms on the adjudicatory branch of the EU Commission has rarely been described as positive.

\subsection{Peoples, Consumers and Citizens}

The difference between the almost right word and the right word is really a large matter. 'tis the difference between the lightning bug and the lightning.

MARK TWAIN

An analysis of the wording used by EU treaties and EU competition law legislation might offer an additional explanation about the reasons for which the latter remained separated from the due process developments taking place elsewhere.

The Treaty of Rome of 1957 had as its main task to establish a common market and to progressively approximate the economic policies of member states, "to promote throughout the Community a harmonious development of economic activities, a continuous and balanced expansion, an increase in stability, an accelerated raising of the standard of living and closer relations between the states belonging to it". ${ }^{31}$ The beneficiaries of the Treaty of Rome

$30 \quad$ Lambert Abdelgaward, op. cit., p. 83 and 89 .

31 Article 2 of the Treaty of Rome. 
appear to be the member states and its "peoples". The word "person" appears in the Treaty of Rome as subject of the free movement of goods, persons, services and capital. The "person" of the Treaty of Rome is a rather passive one, as if carried away by the flow of free movement. The "consumer" is a variation of the "person" and it can be either a beneficiary of common agricultural policy or of competition policy. The word "citizen" does not appear in the Treaty of Rome.

In the same vein, the early Annual Competition Reports indicate that the main beneficiary of the Commission's work in the field of competition is the consumer. The Commission acknowledged that its competition policy

encourages the best possible use of productive resources for the greatest possible benefit of the economy as a whole and for the benefit, in particular, of the consumer. In this respect, the Commission is not only concerned with increasing by means of the rules of competition the quantity of goods available for consumption, but is also taking action to promote better information for consumers. ${ }^{32}$ (emphasis added)

The Treaty of Maastricht was the first document to refer to citizenship and introduced the "citizen" as the subject of EU law. The "citizen" of the Treaty of Maastricht had the right to be in the close vicinity of the decision-making process, had the right to move and reside freely in the territory of the member states and had the right to petition the European Parliament and the European Ombudsman. The focus on the "citizen" continued throughout all of the following Amsterdam, Nice and Lisbon Treaties. However, the competition rules established in the Treaty of Rome remained unchanged.

At the same time, competition policy viewed the "citizen" through its "consumer" lens. Karel van Miert wrote in the introduction to the 1995 Annual Report on Competition that "the single market must first and foremost serve people. It must be ensured, through strict application of the competition rules, that consumers have freedom of choice between quality products at competitive prices". ${ }^{33}$ The same view appears to have been held by all subsequent Competition Commissioners. Commissioner Neelie Kroes wrote that "improving the functioning of markets for the benefit of European consumers and businesses remains at the heart of the European project". ${ }^{34}$

32 Commission of the European Economic Community (1972), quoted above, p. 12.

33 European Commission. XXVth Report on Competition Policy 1995. Luxembourg: Office for Official Publications of the European Communities, 1996, p. 7 .

34 European Comission. Report on Competition Policy 2007. Luxembourg: Office for Official Publications of the European Communities, 2008, p. 5 . 
The more recent Annual Reports on Competition make use of the term "citizen" more often, but the term is still closely associated to the citizen as a consumer. The 2017 Annual Report on Competition highlighted that 2017 marked the 6oth anniversary of the signing of the Treaty of Rome and of EU competition policy. The report noted that,

in the past decades, competition policy has made a big difference in people's lives: European citizens may not always be familiar with competition rules, but they deal with the market every single day. Competition drives businesses to compete on the merits - on prices, quality and innovation - and to meet consumers' needs. By pushing companies to do better, competition puts power in the hands of consumers. ${ }^{35}$ (emphasis added)

Is the difference in wording important in this context? If yes, in which ways? The Cambridge Dictionary defines a "citizen" as "a person who is a member of a particular country and who has rights because of being born there or because of being given rights". ${ }^{36}$

A "consumer" on the other hand is "a person who buys goods or services for their own use". ${ }^{37}$ The word "citizen" has the notion of rights at its core, rights that come into being from a relationship with a country. This relationship implies continuity, loyalty and reciprocity. A "consumer", in contrast, is someone - a state, organization or person - that is defined by the act of purchasing and consumption. This relationship implies discontinuity, opportunism and money or other units that can be used as a measure for the exchange.

Shrubsole noted that the use of the word "consumer" has steadily grown during the 2oth century, slowly replacing the word "citizen" in books, media and policy documents. ${ }^{38}$ Another author found that "unlike the citizen, the consumer's means of expression is limited: while citizens can address every

35 European Commission. Report on Competition Policy 2017. Brussels: СОм(2018) 482 final, p. 2. Available at http://ec.europa.eu/competition/publications/annual_report/2017/partı_ en.pdf accessed on 23 February 2021.

36 Cambridge Online Dictionary, available at: https://dictionary.cambridge.org/dictionary/ english/citizen

37 Cambridge Online Dictionary, available at:https://dictionary.cambridge.org/dictionary/ english/citizen

38 Shrubsole, Guy. "Consumers Outstrip Citizens in British Media." Open Democracy. 5 Mar 2012. Available at https://www.opendemocracy.net/en/opendemocracyuk/consumersoutstrip-citizens-in-british-media/ accessed on 23 February 2021. 
aspect of cultural, social and economic life (...), consumers find expression only in the marketplace". ${ }^{39}$

This shift in terminology can be considered an expression of what Berry called "tyrannese". He wrote: "My impression is that we have seen, for perhaps a hundred and fifty years, a gradual increase in language that is either meaningless or destructive of meaning. And I believe that this increasing unreliability of language parallels the increasing disintegration, over the same period, of persons and communities". ${ }^{40}$ He goes on to say that

in this degenerative accounting, language is almost without the power of designation, because it is used conscientiously to refer to nothing in particular. Attention rests upon percentages, categories, abstract functions. It is not language that the user will very likely be required to stand by or act on, for it does not define any personal ground for standing or acting. Its only practical utility is to support with "expert opinion" a vast, impersonal technological action already begun. (...) It is tyrannical language: tyrannese. ${ }^{41}$

The European Communities initially focused on constructing a Common Market to ensure the free movement of goods, services, persons and capital, and only later on a Union, whose citizens have rights and obligations. On the other hand, the fact that European Competition Policy has remained focused on consumers and has not updated its vocabulary to "citizenry" is surprising. This, however, can partially account for the reticence of competition officials to enlarge due process guarantees during competition law proceedings.

\subsection{Accession of the EU to the ECHR}

The Council of Europe and the European Union have developed in parallel, in largely the same geographic area and on the basis of similar principles. The concepts of human rights and fundamental rights have been key elements of institution-building, both for the Council of Europe and for the European Union. The proposed accession of the European Union to the ECHR highlights,

39 Lewis, Justin, Sanna Inthorn and Karin Wahl-Jorgensen. Citizens or Consumers: What the Media Tell Us about Political Participation: The Media and the Decline of Political Participation. Maidenhead: Open University Press, 2005.

40 Berry, Wendell. Standing by Words. San Francisco: North Point Press, 1983, p. 24.

41 Berry, op. cit., p. $5^{2}$. 
however, the menial and procedural aspects that prevent the successful enforcement of human rights at the supranational level.

According to well-established case-law of the CJEU, fundamental rights form an integral part of the general principles of EU law. For that purpose, the Court of Justice draws inspiration from the constitutional traditions common to the member states and from the guidelines supplied by international treaties for the protection of human rights on which the member states have collaborated or of which they are signatories. ${ }^{42}$

In paragraphs 34 and 35 of the Opinion 2/94, the Court of Justice considered that the European Community had no competence to accede to the ECHR. ${ }^{43}$ Such accession would have required a substantial change in the existing Community system for the protection of human rights in that it would have entailed the entry of the Community into a distinct international institutional system as well as integration of all the provisions of that Convention into the Community's legal order. Such a modification of the system for the protection of human rights in the Community would have been of constitutional significance both to the Community and to the member states and would therefore have gone beyond the scope of the Ec Treaty.

On 7 December 200o, the European Parliament, the Council of the European Union and the Commission proclaimed the Charter of Fundamental Rights of the European Union in Nice. ${ }^{44}$ The Charter, which at that time was not a legally binding instrument, has the principal aim, as is apparent from the preamble thereto, of reaffirming

the rights as they result, in particular, from the constitutional traditions and international obligations common to the Member States, the Treaty on European Union, the Community Treaties, the [ECHR], the Social Charters adopted by the Community and by the Council of Europe and the case-law of the [Court of Justice] and of the [ECtHR]. ${ }^{45}$

42 C-11/70, Internationale Handelsgesellschaft mbH $v$ Einfuhr- und Vorratsstelle für Getreide und Futtermittel, ECLI:EU:C:1970:114, paragraph 4.

C-4/73, Nold KG v Commission, ECLI:EU:C:1974:51, paragraph 13.

In that context, the Court of Justice has stated that the ECHR has special significance: see, in particular, C-26o/89, ERT V DEP, ECLI:EU:C:1991:254, paragraph 41.

C-402/05 P, Kadi and Al Barakaat International Foundation v Council and Commission, ECLI:EU:C:2008:461.

C-415/05 P, Al Barakaat International Foundation $v$ Council and Commission, ECLI:EU:C:2008:30, paragraph 283.

43 ECJ, Avis 2/94, Adhésion de la Communauté à la CEDH, ECLI:EU:C:1996:14O.

44 Avis 2/94, Adhésion de la Communauté à la CEDH, quoted above.

45 See, to that effect, C-540/o3, Parliament v Council, ECLI:EU:C:2006:429, paragraph 38. 
The Treaty of Lisbon, which entered into force on 1 December 2009, amended Article 6 TEU which is worded as follows:

1. The Union recognises the rights, freedoms and principles set out in the [Charter], which shall have the same legal value as the Treaties. The provisions of the Charter shall not extend in any way the competences of the Union as defined in the Treaties.

The rights, freedoms and principles in the Charter shall be interpreted in accordance with the general provisions in Title VII of the Charter governing its interpretation and application and with due regard to the explanations referred to in the Charter, that set out the sources of those provisions.

2. The Union shall accede to the [ECHR]. Such accession shall not affect the Union's competences as defined in the Treaties.

3. Fundamental rights, as guaranteed by the [ECHR] and as they result from the constitutional traditions common to the Member States, shall constitute general principles of the Union's law.

In that regard, Article 218(6)(a)(ii) TFEU provided that the Council was to adopt the decision concluding the agreement on EU accession to the ECHR ('the accession agreement') after obtaining the consent of Parliament. In addition, Article 218(8) states that, for that purpose, the Council is to act unanimously and that its decision is to enter into force after it has been approved by the member states in accordance with their respective constitutional requirements.

The Declaration on Article 6(2) TEU, annexed to the Final Act of the Intergovernmental Conference which adopted the Treaty of Lisbon, states as follows:

The Conference agrees that the Union's accession to the [ECHR] should be arranged in such a way as to preserve the specific features of Union law. In this connection, the Conference notes the existence of a regular dialogue between the [Court of Justice] and the [ECtHR]; such dialogue could be reinforced when the Union accedes to that Convention.

Upon the recommendation of the Commission of 17 March 2010, the Council adopted a decision on 4 June 2010 authorizing the opening of negotiations in relation to the accession agreement, and designated the Commission as negotiator. On 5 April 2013, the negotiations resulted in agreement among the negotiators on the draft accession instruments. The negotiators agreed that all 
those instruments constitute a package and that they are all equally necessary for the accession of the EU to the ECHR.

Later the same year, the European Commission requested the Court of Justice to issue an opinion concerning the compatibility of the proposed accession agreement with the Treaties. The Court of Justice issued its opinion on 18 December 2014 arguing that the envisaged agreement is not compatible with Article 6(2) TEU or with Protocol No 8 EU in that:

- it is liable to adversely affect the specific characteristics and the autonomy of EU law in so far as it does not ensure coordination between Article 53 of the ECHR and Article 53 of the Charter, does not avert the risk that the principle of Member States' mutual trust under EU law may be undermined, and makes no provision in respect of the relationship between the mechanism established by Protocol No 16 and the preliminary ruling procedure provided for in Article 267 TFEU;

- it is liable to affect Article 344 TFEU in so far as it does not preclude the possibility of disputes between Member States or between Member States and the EU concerning the application of the ECHR within the scope ratione materiae of EU law being brought before the ECtHR;

- it does not lay down arrangements for the operation of the co-respondent mechanism and the procedure for the prior involvement of the Court of Justice that enable the specific characteristics of the EU and EU law to be preserved; and

- it fails to have regard to the specific characteristics of EU law with regard to the judicial review of acts, actions or omissions on the part of the EU in Common Foreign and Security Policy matters in that it entrusts the judicial review of some of those acts, actions or omissions exclusively to a nonEU body.

The Court stressed in particular the fact that the EU had a new kind of legal order - the nature of which is peculiar to the EU its own constitutional framework and founding principles, a particularly sophisticated institutional structure and a full set of legal rules to ensure its operation, had consequences as regards the procedure for and conditions of accession to the ECHR. What is more, these essential characteristics of EU law have given rise to a structured network of principles, rules and mutually interdependent legal relations linking the EU and its member states, and its member states with each other, which were now engaged, as is recalled in the second paragraph of Article $1 \mathrm{TEU}$, in a process of creating an ever-closer union among the peoples of Europe.

A great deal of effort has been put into the protection of the specific characteristics and the autonomy of that legal order. For this purpose, the Treaties have established a judicial system intended to ensure consistency and uniformity 
in the interpretation of EU law. The accession of the EU to the ECHR risked endangering this system.

For example, the EU, like any other contracting party, would be subject to external control to ensure the observance of the rights and freedoms the EU would undertake to respect in accordance with Article 1 ECHR. In that context, the EU and its institutions, including the Court of Justice, would be subject to the control mechanisms provided for by the ECHR and, in particular, to the decisions and the judgments of the ECtHR. It is implicit in the very concept of external control that the interpretation of the ECHR by the ECtHR would be binding on the EU and its institutions, including the CJEU.

On the other hand, the interpretation by the Court of Justice of a right recognized by the ECHR would not be binding on the control mechanisms provided for by the ECHR, the ECtHR in particular. The CJEU referred to its case-law that an international agreement providing for the creation of a court responsible for the interpretation of its provisions and whose decisions are binding on the institutions, including the Court of Justice, should not, in principle, be incompatible with EU law, especially when the conclusion of such an agreement is provided for by the Treaties themselves. The competence of the EU in the field of international relations, and its capacity to conclude international agreements, necessarily entails the power to submit to the decisions of a court which is created or designated by such agreements as regards the interpretation and application of their provisions. ${ }^{46}$ Nevertheless, the Court of Justice has also declared that an international agreement may affect its own powers only if the indispensable conditions for safeguarding the essential character of those powers were satisfied and, consequently, there were no adverse effect on the autonomy of the EU legal order. ${ }^{47}$

The CJEU also stressed that

the approach adopted in the agreement envisaged, which is to treat the $\mathrm{EU}$ as a State and to give it a role identical in every respect to that of any other Contracting Party, specifically disregards the intrinsic nature of

46 See Opinions, ECJ, Avis 1/91, Accord EEE - I, ECLI:Eu:C:1991:49o, paragraphs 40 and 70. ECJ, Avis 1/og, Accord sur la création d'un système unifié de règlement des litiges en matière de brevets, ECLI:EU:C:2011:123, paragraph 74 .

47 See Opinions ECJ, Avis 1/oo, Accord sur la création d'un espace aérien européen commun, ECLI:EU:C:2002:231, paragraphs 21, 23 and 26.

Avis 1/og, Accord sur la création d'un système unifié de règlement des litiges en matière de brevets, quoted above, paragraph 76 .

See also, to that effect, C-402/05 P, Kadi and Al Barakaat International Foundation $v$ Council and Commission quoted above, paragraph 282. 
the EU and, in particular, fails to take into consideration the fact that the Member States have, by reason of their membership of the EU, accepted that relations between them as regards the matters covered by the transfer of powers from the Member States to the EU are governed by EU law to the exclusion, if EU law so requires, of any other law. ${ }^{48}$

The Court of Justice has also been keen to protect the preliminary ruling procedure that risked losing its importance due to the accession of the EU to the ECHR. In particular, the Court stressed that a request for an advisory opinion by a court or tribunal of a member state "could trigger the procedure for the prior involvement of the Court of Justice, thus creating a risk that the preliminary ruling procedure provided for in Article $267 \mathrm{TFEU}$ might be circumvented, a procedure which is the keystone of the judicial system established by the Treaties". 49

Lock had already suggested in 2011, in one of the first academic papers covering the accession of the EU to the ECHR, that "accession by the EU to the ECHR raises fundamental questions of constitutional significance". ${ }^{50} \mathrm{He}$ stressed that the accession agreement requires a difficult balancing between the task of preserving the autonomy of the EU legal order and practical and political demands, which might conflict with it. He concluded, that "all this makes the EU a difficult partner in negotiations". ${ }^{51}$ Since then, the topic of the accession of the EU to the ECHR has been analysed both from the point of view of the technical challenges posed by the accession and from the point of view of the relationship between the ECtHR and the EU Courts, which has sometimes been characterized as contradictory. ${ }^{2}$ The Court's opinion leaves

48 ECJ, Avis 2/94, Adhésion de la Communauté à la CEDH, ECLI:Eu:C:1996:140, paragraph 193.

49 ECJ, Avis 2/94, Adhésion de la Communauté à la CEDH, ECLI:Eu:C:1996:14O. Paragraph 198.

$50 \quad$ Lock, Tobias. "Walking on a Tightrope: The Draft Accession Agreement and the Autonomy of the EU Legal Order." Common Market Law Review 48.4 (2011): pp. 1025-1054, p. 1053.

$5^{1}$ Lock, op. cit., p. 1054.

52 Eckes, Christina. "EU Accession to the ECHR: Between Autonomy and Adaptation." The Modern Law Review 76.2 (2013): pp. 254-285.

Dzehtsiarou, Kanstantsin and Pavel Repyeuski. "European Consensus and the EU Accession to the ECHR.” The EU Accession to the ECHR. Eds. Vicky Kosta, Nikos Skoutaris and Vassilis Tzevelekos. Oxford: Hart Publishing, 2014, pp. 309-324.

Lock, Tobias. "The ECJ and the ECtHR: The Future Relationship between the Two European Courts." The Law and Practice of International Courts and Tribunals, 8 (2009): pp. 375-398.

Pavone, Tommaso. "The Past and Future Relationship of the European Court of Justice and the European Court of Human Rights: A Functional Analysis." SSRN Electronic Journal 10.2139 (2012). Available at https://ssrn.com/abstract $=2042867$ accessed on 23 February 2021. 
no doubts as to the fact that the EU accession to the ECHR will have a major impact on EU law.

\subsection{The Charter of Fundamental Rights of the EU}

The Charter of Fundamental Rights of the European Union has been proclaimed on 7 December 2000 and entered into force on 1 December 2009, as part of the Treaty of Lisbon. The growing importance of the Charter and its relationship with other fundamental rights instruments in Europe feeds into the subject of this book.

The Preamble of the Charter announces that the EU contributes to the preservation and to the development of the universal values of human dignity, freedom, equality and solidarity. To this end the EU must "strengthen the protection of fundamental rights in the light of changes in society, social progress and scientific and technological developments by making those rights more visible".

Furthermore, the Charter reaffirms the fundamental rights as they result from the constitutional traditions and international obligations common to the Member States, the ECHR, the Social Charters adopted by the Union and by the Council of Europe and the case-law of the CJEU and of the ECtHR. Therefore, the Charter should be interpreted with due regard to the explanations.

According to Article 51 of the Charter, the terms of the Charter are addressed to the institutions, bodies, offices and agencies of the EU and to the national authorities when they are implementing EU law.

In order to provide the EU institutions and the EU Member States when implementing EU law with assistance and expertise relating to fundamental rights, the EU established the EU Agency for Fundamental Rights (the Agency). ${ }^{53}$ The Agency does large-scale surveys, comparative legal or social research and handbooks for legal professionals. The Multi-Annual framework defined nine thematic areas for the Agency's work: (a) victims of crime and access to justice; (b) equality and discrimination; (c) information society and, in particular, respect for private life and protection of personal data; (d) judicial cooperation; (e) migration, borders, asylum and

Gragl, Paul. The Accession of the European Union to the European Convention on Human Rights. Oxford: Hart Publishing, 2014, p. 263.

53 Council Regulation (EC) No 168/2007 of 15 February 2007 establishing a European Union Agency for Fundamental Rights, OJ L 53, 22.2.2007, pp. 1-14. 
integration of refugees and migrants; (f) racism, xenophobia and related intolerance; (g) rights of the child; (h) integration and social inclusion of Roma. ${ }^{54}$

In 2010, the Commission adopted a strategy to monitor and ensure the effective implementation of the rights and freedoms enshrined in the Charter. ${ }^{55}$ There, the Commission highlighted that the Charter was an innovative instrument because it brought "together in one text all the fundamental rights protected in the Union, spelling them out in detail and making them visible and predictable". 56

The adoption of the Charter has been hailed by the academia as a longawaited text. Morano-Foadi and Andreadakis performed in 2010 interviews with 19 CJEU judges and Advocates General about the importance of the entry into force of the Charter. Despite the fact that interviewees highlighted the central role played by the Charter, the respondents split into two groups: "the majority of them, more optimistic, believing that a new era of integration, based on rights, was inaugurated with Lisbon; and those a little bit more cautious, who felt that that was not the case". ${ }^{57}$ The second group of respondents underlined the fact that the CJEU has "recognised and protected rights for decades" and, not without importance, "questioned the balance of interests and rights". 58

A major concern raised by the opponents of the Treaty of Lisbon was that "the new legally binding status of the Charter would lead to an American-style legal revolution whereby the Court of Justice would have the jurisdiction to review national measures for their conformity with EU fundamental rights regardless of the absence of any link with Union law".59

At the same time, many authors have placed the Charter within the "unsettled question of complexity inherent in talking about human rights within a

54 Council Decision (EU) 2017/2269 of 7 December 2017 establishing a Multiannual Framework for the European Union Agency for Fundamental Rights for 2018-2022, OJ L 326, 9.12.2017, pp. 1-4, article 2 .

55 European Commission. Communication from the Commission. Strategy for the effective implementation of the Charter of Fundamental Rights by the European Union. сом/2010/ 0573 final.

$5^{6}$ Strategy for the effective implementation of the Charter of Fundamental Rights by the European Union, quoted above, p. 3.

57 Morano-Foadi, Sonia and Stelios Andreadakis. "Reflections of the Architecture of the EU after the Treaty of Lisbon: The European Judicial Approach to Fundamental Rights." European Law Journal 17.5 (2011): pp. 595-610, p. 599.

58 Morano-Foadi and Andreadakis, op. cit.

59 Groussot, Pech and Petursson, op. cit., p. 15. 
framework of autonomy and supremacy".60 Thus, Alonso Garcia, commenting on Article 53 of the Charter noted that

this clause, insofar as it entails the potential displacement of the instrument of which it forms part by others which offer a greater level of protection, poses in the case of the Charter a first complication in its interpretation: unlike the international treaties confined to human rights, which have the clear vocation of complementing the national system of protection, the Charter is part of a context, the Union context, which is constructed in conceptual terms as an autonomous legal order with an integrating vocation that tends to displace, by means of the principle of supremacy, the disparities between the Member States. ${ }^{61}$

Indeed, Articles $5^{2}$ and 53 of the Charter raise important questions of interpretation concerning the relationship of the Charter with the ECHR and the ECtHR.

Article 52, titled Scope and interpretation of the rights and principles, states in paragraph 3 that insofar as the Charter contains rights which correspond to rights guaranteed by the ECHR, "the meaning and scope of those rights shall be the same as those laid down by the said Convention. This provision shall not prevent Union law providing more extensive protection".

Paragraph 4 of Article 52, by contrast, stipulates that insofar as the Charter recognizes fundamental rights "as they result from the constitutional traditions common to the Member States, those rights shall be interpreted in harmony with those traditions".

Article 53 of the Charter, titled Level of protection, states that nothing in the Charter "shall be interpreted as restricting or adversely affecting human rights and fundamental freedoms, as recognized, in their respective fields of application, by Union law and international law and by international agreements to which the Union or all the Member States are party, including the European Convention for the Protection of Human Rights and Fundamental Freedoms, and by the Member States' constitutions".

Arold Lorenz, Groussot and Petursson have argued that Article 52 was "the most complex provision of the Charter and can be seen as akin to a Pandora's

6o Alonso Garcia, R. "The General Provisions of the Charter of Fundamental Rights of the European Union." European Law Journal 8.4 (2002): pp. 492-514, p. 510.

61 Alonso Garcia, op. cit., pp. 507-508. 
Box".62 They call Article 52 the "limitation, homogeneity and clarification clause" which regulates "the functioning of the rights within the Charter (internal regulation) and its relationship with other sources of law related to the protection of human rights in Europe (external regulation)".63 In addition, Morano-Foadi and Andreadakis observed that pursuant to Article $5^{2}$ of the Charter, "the jurisprudence of the ECtHR constitutes the lowest minimum standard to be respected within the Union". ${ }^{64}$ This, in turn, "leads the EU to be indirectly bound by the ECHR, as it must always be followed when restricting fundamental rights in the EU to ensure the EU maintains the same level of protection". 65

Advocate General Bot discussed Article 53 of the Charter in Melloni. He highlighted that

Article 53 of the Charter supplements the principles stated in Articles 51 and $5^{2}$ thereof (...), by pointing out that, in a system in which the pluralism of sources of protection of fundamental rights prevails, the Charter is not intended to become the exclusive instrument for protecting those rights and, also, that it cannot have the effect, on its own, of adversely affecting or reducing the level of protection resulting from those different sources in their respective fields of application. ${ }^{66}$

The CJEU did not refer to the Charter as a source of inspiration until 2006. One month after the entry into force of the Treaty of Lisbon, the CJEU adopted the Kücükdeveci decision in which the Charter's status has been mentioned for the first time. ${ }^{67}$ Since then, the Charter has been used by the EU Courts as

62 Arold Lorenz, Nina-Louisa, Xavier Groussot and Gunnar Thor Petursson. The European Human Rights Culture - A Paradox of Human Rights Protection in Europe? Leiden: Martinus Nijhoff Publishers, 2013, p. 192.

63 Arold Lorenz, Groussot and Petursson, op. cit.

64 Morano-Foadi and Andreadakis, op. cit., p. 597.

65 Douglas-Scott, Sionaidh. "The European Union and Human Rights after the Treaty of Lisbon." Human Rights Law Review 11.4 (2011), pp. 645-682, p. 655 .

66 Opinion of Advocate General, C-399/11, Stefano Melloni $v$ Ministerio Fiscal, ECLI:EU:C:2012:6oo, paragraph 131.

67 C-555/o7, Kücükdeveci v Swedex GmbH \& Co. KG, ECLI:Eu:C:2010:21. For a commentary, see Wiesbrock, Anja. "Case Note - Case C-555/o7, Kucukdeveci v. Swedex, Judgment of the Court (Grand Chamber) of 19 January 2010." German Law Journal 11.5 (2010): pp. 539-550. 
regular source of inspiration, including for the interpretation of the right to a fair trial, which is the subject of the current book. However, as I will show in the following chapters, the Charter cannot be deemed to have clarified the fair trial issues raised by this book. 